DISRESPECTFUL DEMOCRACY 

EMILY SYDNOR

\section{DISRESPECTFUL DEMOCRACY}

The Psychology of Political Incivility

Columbia University Press / New York 


\author{
幽 \\ Columbia University Press \\ Publishers Since I893 \\ New York Chichester, West Sussex \\ cup.columbia.edu \\ Copyright $\left({ }_{2} 2019\right.$ Columbia University Press \\ All rights reserved \\ Library of Congress Cataloging-in-Publication Data \\ A complete CIP record is available from the Library of Congress. \\ ISBN 978-o-23I-I8924-8 (cloth : alk. paper) \\ ISBN 978-o-231-54825-o (e-book) \\ LCCN: 2019021844 \\ Columbia University Press books are printed on permanent \\ and durable acid-free paper. \\ Printed in the United States of America \\ Cover design: Lisa Hamm
}

